Journal of Advanced College of Engineering and Management, Vol. 5, 2019

\title{
EXPERIMENTAL ANALYSIS ON THE PROPERTIES OF CONCRETE BRICK WITH PARTIAL REPLACEMENT OF SAND BY SAW DUST AND PARTIAL REPLACEMENT OF COARSE AGGREGATE BY EXPANDED POLYSTYRENE
}

\author{
Anjana Ghimire ${ }^{1}$, Sanjeev Maharjan ${ }^{2}$ \\ ${ }^{1}$ Construction Instructor, Balaju School of Engineering \& Technology, CTEVT \\ ${ }^{2}$ Assistant Professor, Department of Mechanical Engineering,Pulchowk Campus, T.U.
}

\begin{abstract}
An experimental study had been conducted to study the effects of saw dust and EPS as partial replacement of sand and coarse aggregate in various percentages such as $0 \%, 10 \%, 20 \%$ and $30 \%$ in concrete brick samples of M20 and M15 Grade. Compressive strength, Bulk density and Water absorption of prepared saw dust and EPS M20 and M15 concrete brick were determined. The properties of materials were first determined before the conduction of experimental works. The normal consistency, initial and final setting time and compressive strength of cement used for the experiment were found as $31 \%$, 115 minutes, 265 minutes and $39.5 \mathrm{~N} / \mathrm{mm}^{2}$ respectively. Sieve analysis to determine the particle size distribution of sand, coarse aggregates, saw dust and EPS was performed. From the sieve analysis, the nominal maximum size of sand, coarse aggregate, saw dust and EPS used for preparing concrete brick sample were $2.36 \mathrm{~mm}, 12.5 \mathrm{~mm}, 2.36 \mathrm{~mm}$ and $4.75 \mathrm{~mm}$ respectively. Impact value of coarse aggregate obtained was $11.20 \%$.

The experimental results showed that water absorption of prepared M15 and M20 concrete brick samples increased with increase in percentage replacement of sand by saw dust and EPS by coarse aggregate. Compressive strength and Bulk density of prepared M15 and M20 concrete brick sample decreased with increase in percentage content of saw dust and EPS. The results showed that the partial replacement of sand by saw dust and coarse aggregate by EPS in concrete brick sample had sufficient strength as compared to common bricks.
\end{abstract}

Keywords: Compressive Strength; Bulk Density; Water Absorption; Sand; Brick

\section{Introduction}

Increase in the developmental activities all over the world has led to increase in demand for construction materials. Most of the construction materials for construction are obtained from the environment and numerous environmental problems and natural disasters occurred due to high extraction of those materials from nature. So, it is needed to focus on the future development, while protecting the environment. There is a strong need to utilize alternative materials for sustainable development. Waste materials such as sawdust and expanded polystyrene have caused environmental pollution. Use of waste polystyrene and saw dust waste in concrete production not only solves the problem of disposing these wastes but also helps preserve natural resources. The most widely used fine aggregate for making concrete is the natural sand mined from the riverbeds. However, the availability of river sand for the preparation of concrete is becoming demand due to the excessive nonscientific method of mining from the riverbeds, lowering of water table, sinking of the bridge piers, etc. Large quantity of sawdust wastes used in this research is currently disposed in sanitary landfills or open dumped into uncontrolled waste pits and open areas.

Also the coarse aggregate could be partially replaced by Expanded Polystyrene (EPS) which is a packing material in the form of beads. It is posing a threat to waste disposal as well as for waste management. This material is a cause of concern to environmentalists. Therefore, this research has been done to study the utilization of waste EPS and sawdust in concrete technology reducing environmental effects. 
These replacement exhibits many benefits over the traditional concrete including reduction in weight of the structure by reducing the dead loads transmitted to the foundation, high economy compared to normal weight concrete, reduced damage and prolonged life of formwork due to lower exerted pressure, easy handling, mixing and placing as compared with other types of concretes, improved absorbent properties due to its high void ratio(Kumar, et al.,2014). The overall relevance of concrete in virtually all civil engineering practice and building construction works cannot be overemphasized (Adewuyi \& Adegoke, 2008). Concrete is a combination of cement, fine and coarse aggregates and water, which are mixed in a particular proportion to get a particular strength. The cement and water react together chemically to form a paste, which binds the aggregate particles together. The mixture sets into a rock-like solid mass, which has considerable compressive strength but little resistance in tension(Agbede \& Monash, 2009). The high and increasing cost of these materials has greatly hindered the development of shelter and other infrastructural facilities in developing countries (Olutoge, 2010).

\section{Literature Review}

Oyedepo et al.,(2014) investigated the properties of concrete using sawdust as partial replacement for sand. The concrete mix ratio of 1:2:4 was prepared using water/cement of 0.65 with $0 \%, 25 \%, 50 \%$, $75 \%$ and $100 \%$ sawdust as partial replacement for fine sand. The coefficient of uniformity and coefficient of curvature of the sand used in this study was 1.049 and 1.324 respectively which shows that the sand is a well graded sand as it does not exceed the range of 1 and 3 for; and maximum of 6 for specified by the British standard. The aggregate crushing value (ACV) obtained is 43.75 which is within the specified value of 45 as specified by the British standard (BS 812-110 1992). However, values of $40 \mathrm{~mm}, 9 \mathrm{~mm}$ and $5 \mathrm{~mm}$ respectively was obtained for workability at $0 \%, 25 \%$ and $50 \%$ addition of sawdust as partial replacement for sand, while $14.15 \mathrm{~N} / \mathrm{mm} 2,12.96 \mathrm{~N} / \mathrm{mm} 2$ and 11.93 $\mathrm{N} / \mathrm{mm} 2$, were obtained for compressive strength with $25 \%, 75 \%$ and $100 \%$ sawdust as partial replacement. The Compressive strength values obtained were found not to conform to the minimum requirement of $17 \mathrm{~N} / \mathrm{mm} 2$ for light weight concrete. Using sawdust in a proportion greater than $25 \%$ replacement of sand is however detrimental to strength and density properties of concrete.

Boob (2014) studied the performance of sawdust in low cost sandcrete blocks. The blocks of 100* 100* $100 \mathrm{~mm}$ were considered for test report. Various mix proportions providing (cement: fine aggregate (sand + sawdust) tested were: $1: 4(0 \%, 5 \%, 10 \%, 15 \% \& 20 \%$ sawdust replacement) $1: 6$ $(0 \%, 5 \%, 10 \%, 15 \% \& 20 \%$ sawdust replacement $) 1: 8(0 \%, 5 \%, 10 \%, 15 \%$ \& $20 \%$ sawdust replacement. The 1:6 cement sand mix with $15 \%$ sawdust replacement gives strength of $4.5 \mathrm{~N} / \mathrm{mm} 2$ $/ \mathrm{cm} 2$ which is reasonable and economical to be used for the partition walls in frame structure. Density of block reduces with increase in the percentage of sawdust. 1:6 cement sand with 15\% sawdust replacement is found to be suitable from the point of view of strength as well as density, since for this ratio density is $2000 \mathrm{~kg} / \mathrm{m} 3$. Water absorption capacity increases with increase $\%$ of sawdust. Larger absorption of water causes the reduction in the strength. However, for 1:6 proportions with $15 \%$ sawdust replacement, water absorption found to be within reasonable limit.

Mandlik et al., (2013) studied about the EPS concrete. The main aim of this study was to achieve a mix design for Lightweight EPS Concrete with density lesser than $1800 \mathrm{~kg} / \mathrm{m}^{3}$ and enough high compressive strength so that it can be used in construction purpose. The study concluded that expanded polystyrene concrete has scope for nonstructural applications, like wall panels, partition walls, etc.

Gawale et al., (2016)developed a new structural light weight concrete by completely replacing coarse aggregate in concrete by expanded polystyrene (EPS) beads. Their findings have shown that the 
lightweight concrete using EPS beads has a desirable strength to be an alternative construction material for the construction of partition wall, foot path, parapet wall, bed concrete.

Although various researches has been conducted in analyzing strength of concrete by replacing its constituent parts with waste products, the research has not been done by replacing both sand and coarse aggregate with saw dust and EPS.

\section{Research Methodology}

The whole research is based on laboratory experiment so the approach of research adopted here is Experimental Research.

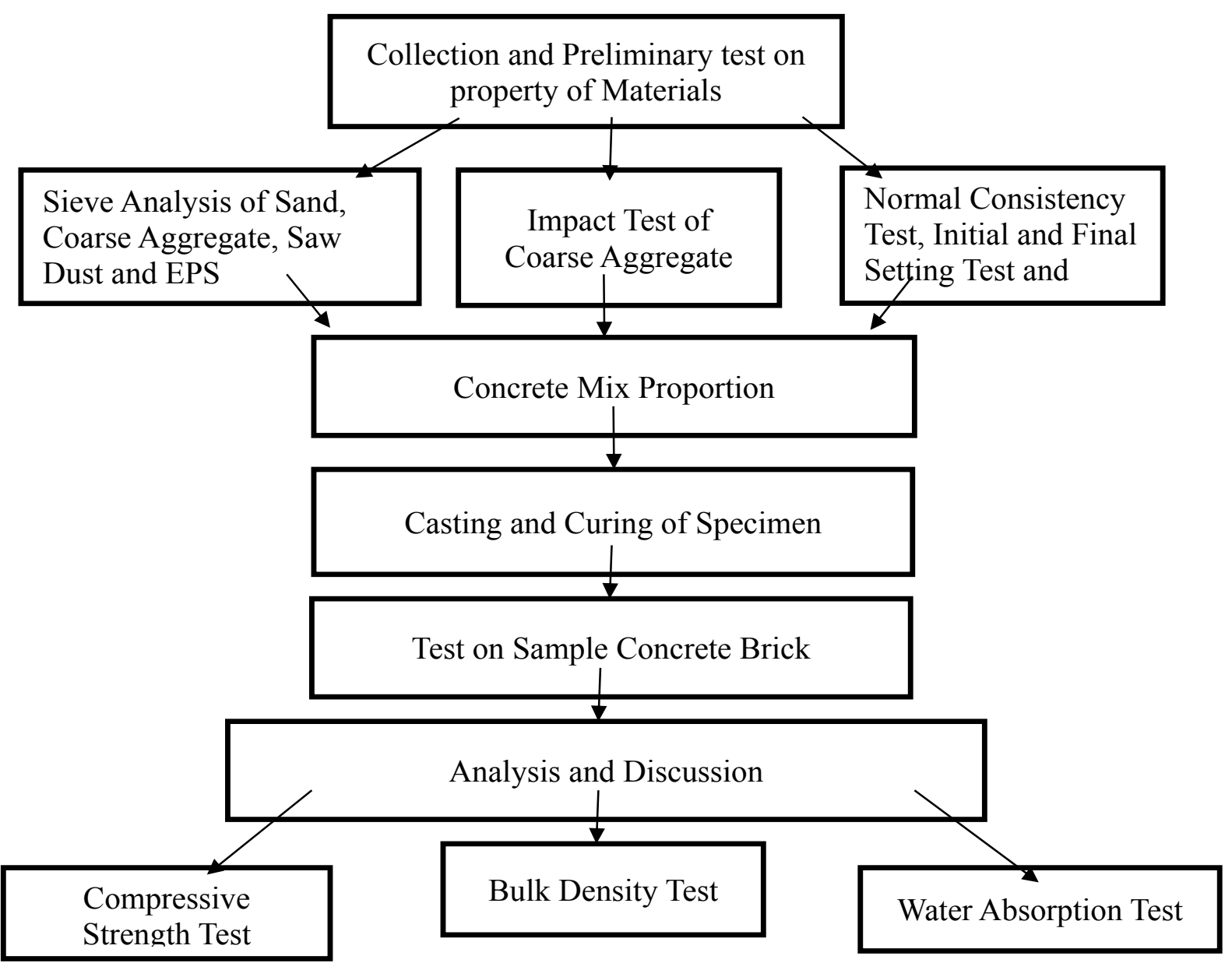

Figure 1: Methodological Framework

\section{Materials Used}

Materials used in this experimental research work were cement, sand, coarse aggregates, EPS, saw dust and water. Cement used was Ordinary Portland Cement. The properties of materials were first determined before the conduction of experimental works. The normal consistency, initial and final setting time and compressive strength of cement used for the experiment were found as $31 \%, 115$ minutes, 265 minutes and $39.5 \mathrm{~N} / \mathrm{mm}^{2}$ respectively. Sieve analysis to determine the particle size distribution of sand, coarse aggregates, saw dust and EPS was performed. From the sieve analysis, the nominal maximum size of sand, coarse aggregate, saw dust and EPS used for preparing concrete brick sample were $2.36 \mathrm{~mm}, 12.5 \mathrm{~mm}, 2.36 \mathrm{~mm}$ and $4.75 \mathrm{~mm}$ respectively. Also, Impact value of coarse aggregate obtained was $11.20 \%$. 


\section{Sample Preparation}

In the process of sample preparation six moulds of dimensions $240 \mathrm{~mm}$ x $115 \mathrm{~mm}$ x $57 \mathrm{~mm}$ were prepared in order to compare properties with common standard brick found in Nepal. Different samples of M20 and M15 grade concrete partially replacing sand by saw dust and EPS by coarse aggregate were made. Table 1 shows that various composition of M20 grade concrete bricks.

Table 1: Composition of various M20 grade brick samples

\begin{tabular}{|c|c|c|c|c|}
\hline $\begin{array}{l}\text { Cement:(Sand and Saw } \\
\text { dust):(EPS and Coarse } \\
\text { Aggregate) }\end{array}$ & $\begin{array}{l}\text { Sand } \\
\text { Replacement by } \\
\text { Saw Dust (\%) }\end{array}$ & $\begin{array}{l}\text { Coarse } \\
\text { Aggregate } \\
\text { Replacement by } \\
\text { EPS (\%) }\end{array}$ & $\begin{array}{l}\text { Sample } \\
\text { Type }\end{array}$ & Sample \\
\hline \multirow{12}{*}{ 1:1.5:3 (By Volume) } & \multirow{3}{*}{0} & \multirow{3}{*}{0} & \multirow{3}{*}{ A } & $\bar{A} 1$ \\
\hline & & & & $\mathrm{A} 2$ \\
\hline & & & & A3 \\
\hline & \multirow{3}{*}{10} & \multirow{3}{*}{10} & \multirow{3}{*}{$\mathrm{B}$} & $\mathrm{B} 1$ \\
\hline & & & & $\mathrm{B} 2$ \\
\hline & & & & B3 \\
\hline & \multirow{3}{*}{20} & \multirow{3}{*}{20} & \multirow{3}{*}{$\mathrm{C}$} & $\mathrm{C} 1$ \\
\hline & & & & $\mathrm{C} 2$ \\
\hline & & & & $\mathrm{C} 3$ \\
\hline & \multirow{3}{*}{30} & \multirow{3}{*}{30} & \multirow{3}{*}{$\mathrm{D}$} & D1 \\
\hline & & & & D2 \\
\hline & & & & D3 \\
\hline
\end{tabular}

Three samples for each sample type A, B, C, D were made for various experimental test. All together 12 samples were made for M20 grade concrete brick. Sample type A, B, C, D were made replacing $0 \%, 10 \%, 20 \%$, and $30 \%$ sand by saw dust and EPS by coarse aggregate respectively. Volume batching was used for the mix. 
Table 2: Composition of various M15 grade brick samples

\begin{tabular}{|c|c|c|c|c|}
\hline $\begin{array}{l}\text { Cement:(Sand and Saw } \\
\text { dust):(EPS and Coarse } \\
\text { Aggregate) }\end{array}$ & $\begin{array}{l}\text { Sand Replacement } \\
\text { by Saw Dust (\%) }\end{array}$ & $\begin{array}{l}\text { Coarse Aggregate } \\
\text { Replacement by } \\
\text { EPS (\%) }\end{array}$ & Sample Type & Sample \\
\hline \multirow{12}{*}{ 1:2:4 (By Volume) } & \multirow{3}{*}{0} & \multirow{3}{*}{0} & \multirow{3}{*}{ E } & E1 \\
\hline & & & & E2 \\
\hline & & & & E3 \\
\hline & \multirow{3}{*}{10} & \multirow{3}{*}{10} & \multirow{3}{*}{$\mathrm{F}$} & F1 \\
\hline & & & & $\mathrm{F} 2$ \\
\hline & & & & F3 \\
\hline & \multirow{3}{*}{20} & \multirow{3}{*}{20} & \multirow{3}{*}{ G } & G1 \\
\hline & & & & $\mathrm{G} 2$ \\
\hline & & & & G3 \\
\hline & \multirow{3}{*}{30} & \multirow{3}{*}{30} & \multirow{3}{*}{$\mathrm{H}$} & $\mathrm{H} 1$ \\
\hline & & & & $\mathrm{H} 2$ \\
\hline & & & & $\mathrm{H} 3$ \\
\hline
\end{tabular}

Table 2 shows various compositions of M20 grade concrete bricks. Three samples for each sample type E, F, G, H were made for various experimental tests. All together 12 samples were made for M15 grade concrete brick. Sample type E, F, G, H were made replacing $0 \%, 10 \%, 20 \%$, and $30 \%$ sand by saw dust and EPS by coarse aggregate respectively. All together 24 concrete brick sample were prepared for laboratory test.

Concrete used for preparing brick was manually mixed and compacted in the brick mould in three layers. Samples prepared were left in mould still for 24 hours. After 24 hours, sample prepared were kept in curing tank for 28 days. Compressive strength, Bulk density and Water absorption test of prepared concrete brick sample was done after 28 days of curing.

\section{Result and Discussion}

The experimental results obtained are shown in Table 3. The average value of result obtained of three samples in each sample type is considered.

Table 3: Result of various samples prepared

\begin{tabular}{|l|l|l|l|l|}
\hline $\begin{array}{l}\text { Percentage of Saw } \\
\text { dust and EPS }\end{array}$ & $\begin{array}{l}\text { Compressive Strength } \\
\left(\mathrm{N} / \mathrm{mm}^{2}\right)\end{array}$ & $\begin{array}{l}\text { Bulk Density } \\
\left(\mathrm{kg} / \mathrm{m}^{3}\right)\end{array}$ & Water Absorption (\%) \\
\hline \multicolumn{3}{|l|}{ For M20 Grade Concrete } & 2400 & 1.99 \\
\hline $0 \%$ & 17.50 & 2273 & 2.44 \\
\hline $10 \%$ & 13.68 & $\begin{array}{l}\text { Compressive Strength } \\
\left(\mathrm{N} / \mathrm{mm}^{2}\right)\end{array}$ & $\begin{array}{l}\text { Bulk Density } \\
\left(\mathrm{kg} / \mathrm{m}^{3}\right)\end{array}$ & Water Absorption (\%) \\
\hline $\begin{array}{l}\text { Percentage of Saw } \\
\text { dust and EPS }\end{array}$
\end{tabular}

jacem, Vol.4, 2018 Experimental Analysis On The Properties Of Concrete Brick With Partial Replacement Of Sand By Saw Dust and Partial Replacement Of Coarse Aggregate By Expanded Polystyrene 
For M20 Grade Concrete

\begin{tabular}{|l|l|l|l|}
\hline $20 \%$ & 8.21 & 2114 & 3.25 \\
\hline $30 \%$ & 7.49 & 2009 & 3.59 \\
\hline \multicolumn{4}{|l|}{ For M15 Grade Concrete } \\
\hline $0 \%$ & 14.73 & 2364 & 3 \\
\hline $10 \%$ & 11.23 & 2227 & 4.96 \\
\hline $20 \%$ & 7.25 & 2069 & 5.04 \\
\hline $30 \%$ & 5.92 & 1985 & 5.05 \\
\hline
\end{tabular}

From the obtained result, it is seen that compressive strength and bulk density of prepared concrete sample decreased with increased in percentage change of saw dust and EPS whereas water absorption increased with increased in percentage change of saw dust and EPS.

\section{Variation of compressive strength with bulk density}

From figure 2, it is seen that with increase in bulk density, the compressive strength of concrete brick sample increases.

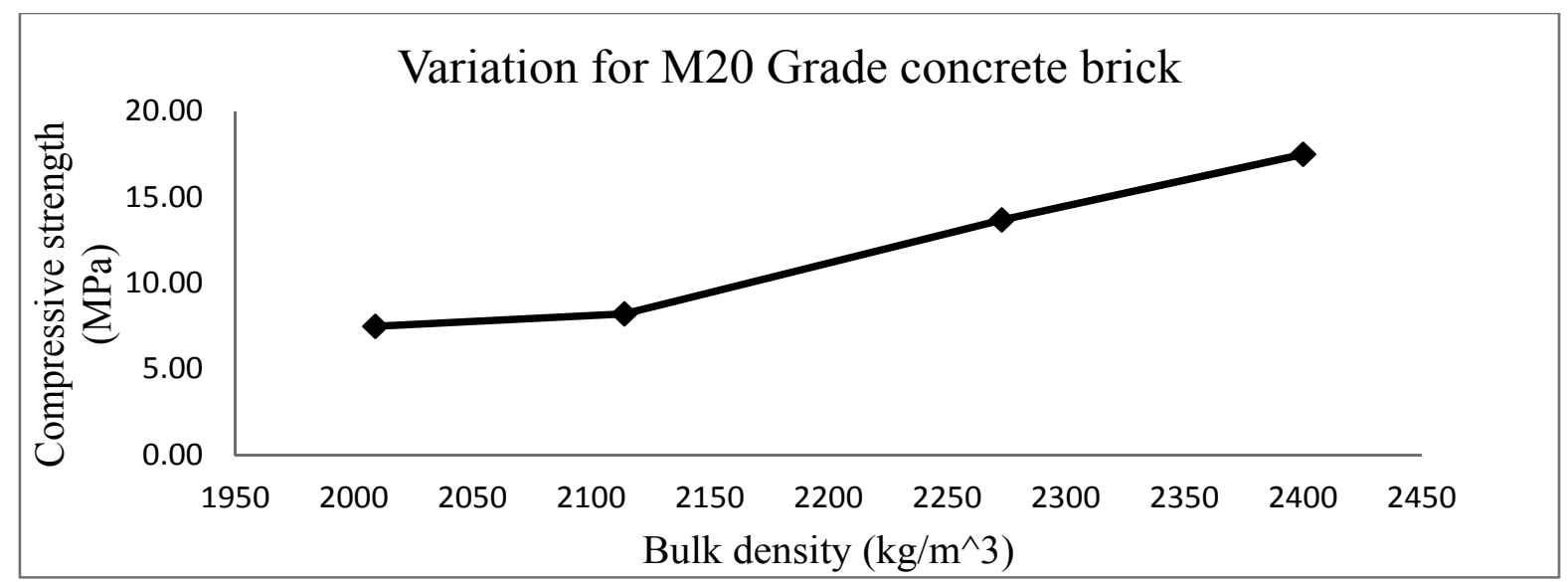

Figure 2: Variation of Compressive strength with bulk density of M20 grade sample

Average value of compressive strength and bulk density of M20 grade concrete brick sample prepared with $0 \%, 10 \%, 20 \%, 30 \%$ replacement of sand and coarse aggregate by saw dust and EPS is plotted. Thus the result obtained shows that compressive strength is directly proportional to bulk density.

It is seen that from figure 3, compressive strength increases with increase in value of bulk density of M15 grade concrete brick sample. 


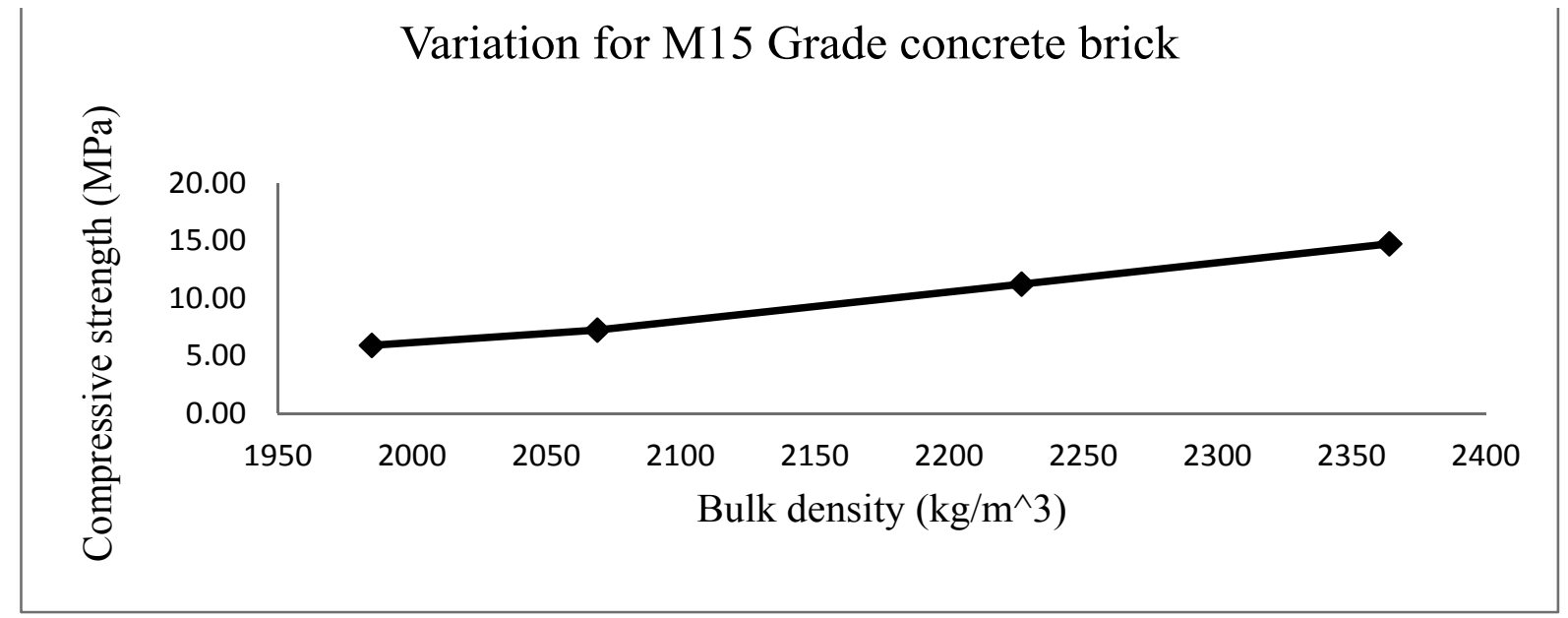

Figure3: Variation of Compressive strength with bulk density of M15 grade sample

\section{Variation of Compressive Strength with Water Absorption}

Average value of compressive strength and water absorption of M20 grade concrete brick sample prepared with $0 \%, 10 \%, 20 \%, 30 \%$ replacement of sand and coarse aggregate by saw dust and EPS is plotted. Thus the result obtained shows that compressive strength decreases with increase in water absorption value.

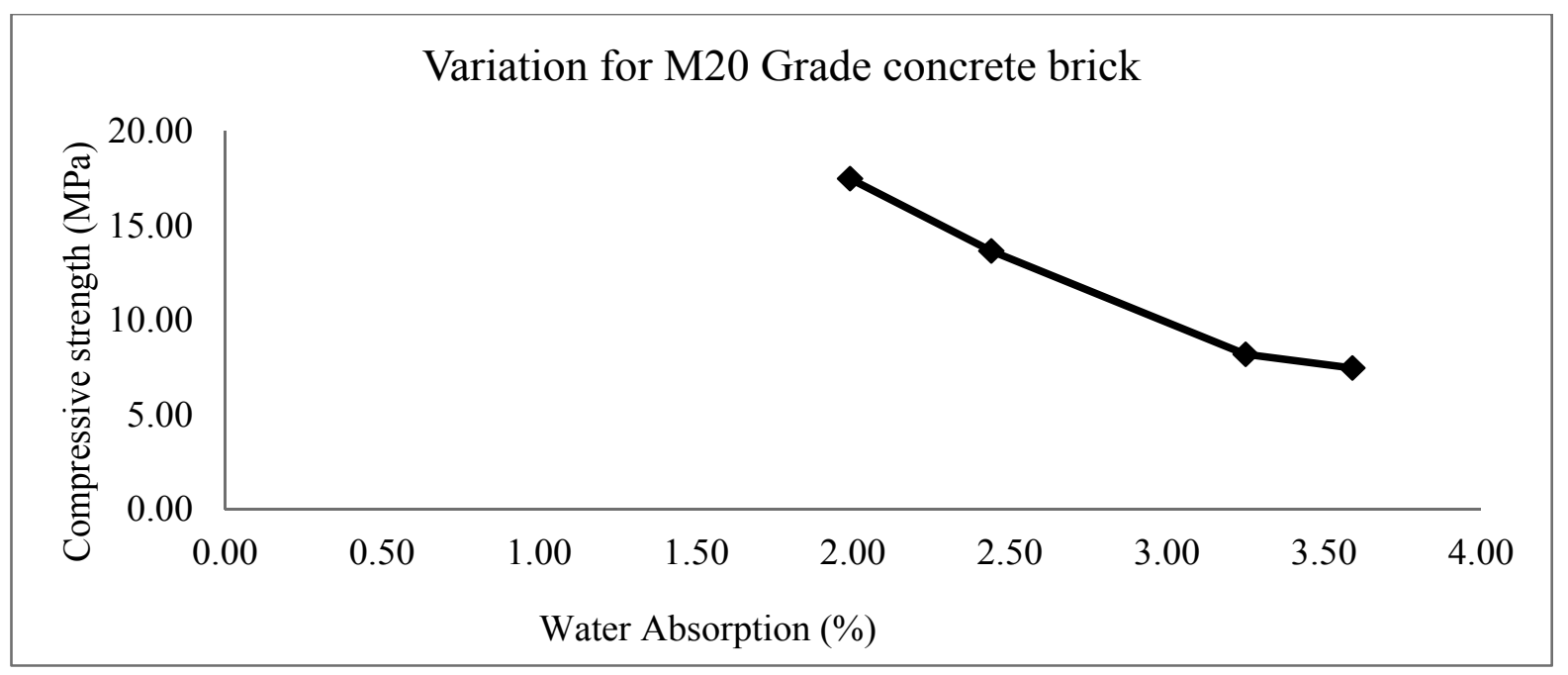

Figure 4: Variation of Compressive strength with water absorption of M20 grade sample

As water absorption value increases, compressive strength of prepared concrete brick sample decreases. 


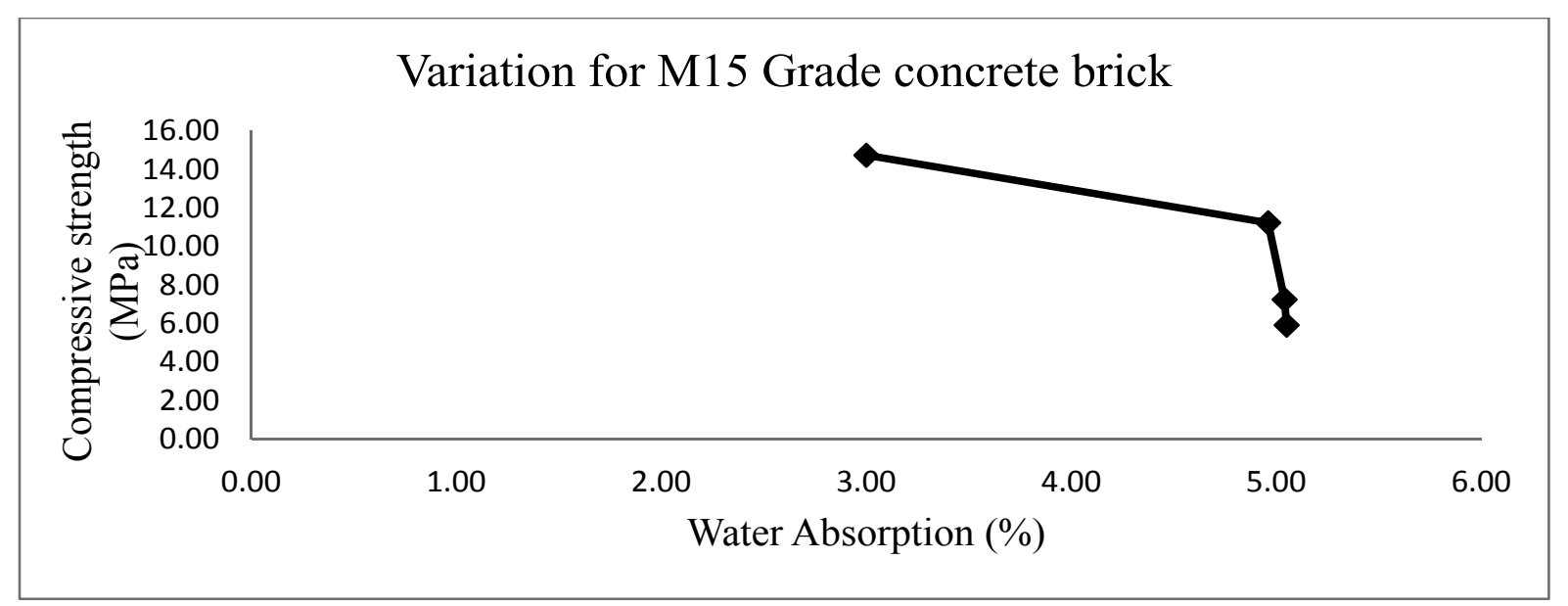

Figure 5: Variation of Compressive strength with water absorption of M15 grade sample

From figure 5, obtained curve after plotting compressive strength verses water absorption of M15 grade concrete brick sample shows that compressive strength decreases with increase in water absorption percentage.

\section{Variation of Bulk Density with Water Absorption}

From figure 6, graph plotted between average bulk density and water absorption, it is observed that bulk density decreases with increase in water absorption percentage.

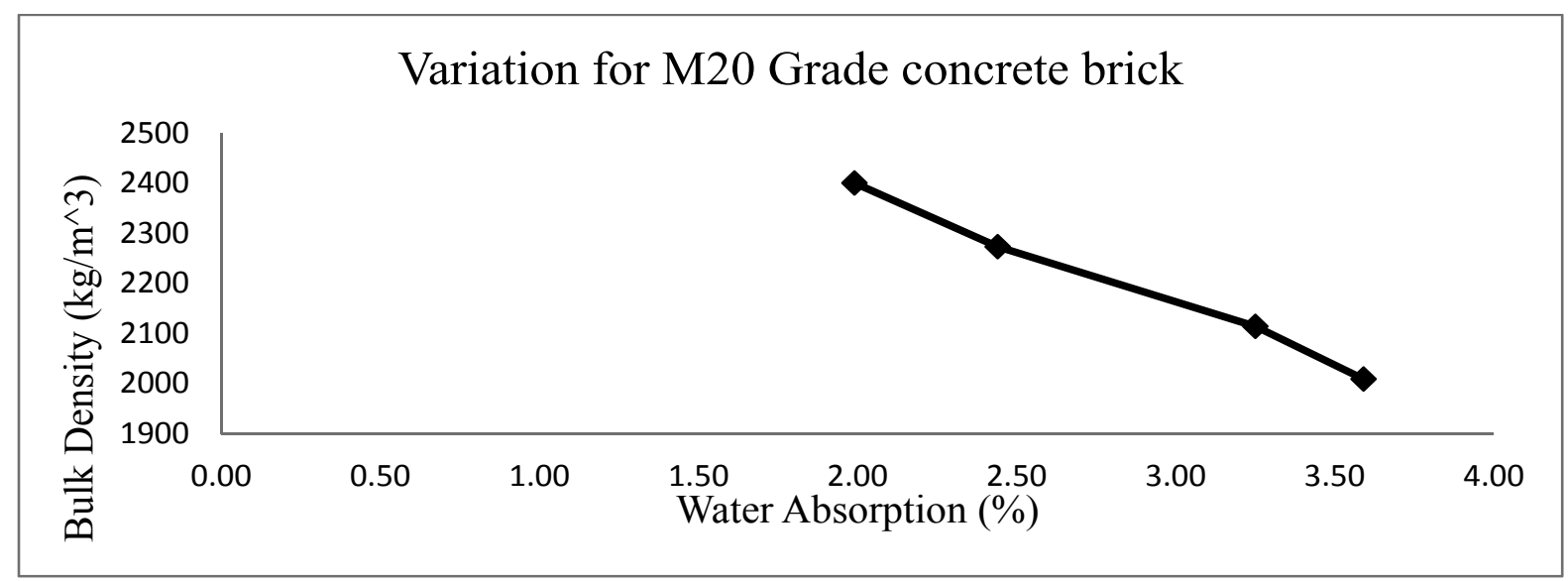

Figure 6: Variation of Bulk Density with water absorption of M20 grade sample

Increase in water absorption value, makes concrete brick sample lighter in weight. Thus result in decrease of bulk density of M20 grade concrete brick sample. 


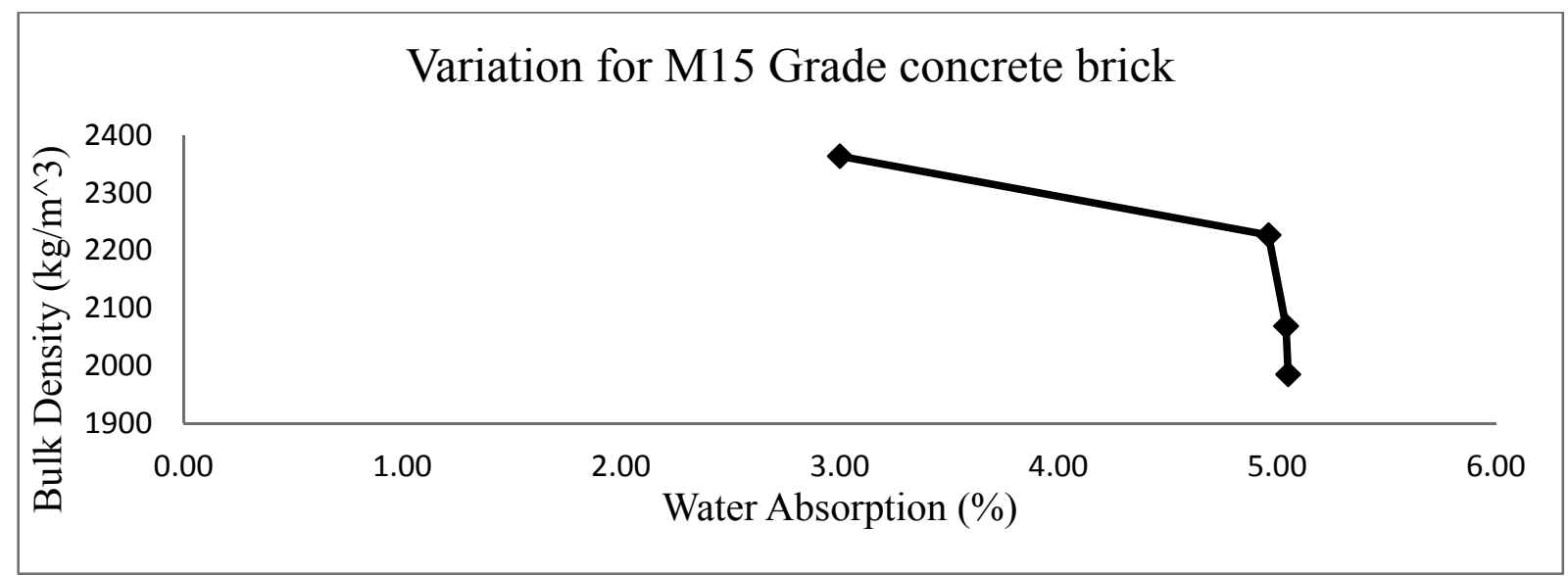

Figure 7: Variation of Bulk Density with water absorption of M15 grade sample

From figure 7, it is cleared that increase in bulk density of concrete brick sample occurred when there is decrease in water absorption value.

\section{Conclusion}

The compressive strength of M20 concrete brick sample varied between $17.5 \mathrm{~N} / \mathrm{mm}^{2}$ to $7.49 \mathrm{~N} / \mathrm{mm}^{2}$. This showed that with increase in percentage replacement of sand by saw dust and coarse aggregate by EPS, the compressive strength of concrete decreases. The compressive strength of M15 concrete brick sample varied between $14.73 \mathrm{~N} / \mathrm{mm}^{2}$ to $5.92 \mathrm{~N} / \mathrm{mm}^{2}$. This showed that with increase in percentage replacement of sand by saw dust and coarse aggregate by EPS, the compressive strength of concrete decreases. The bulk density of M20 concrete brick sample varied between $2400 \mathrm{Kg} / \mathrm{m}^{3}$ to $2009 \mathrm{Kg} / \mathrm{m}^{3}$. This indicated that the decrease in bulk density with the increase in percent replacement of sand by saw dust and coarse aggregate by EPS. The results showed that the concrete become lightweight concrete with the increase in amount of saw dust and EPS. The bulk density of M15 concrete brick sample varied between $2364 \mathrm{Kg} / \mathrm{m}^{3}$ to $1985 \mathrm{Kg} / \mathrm{m}^{3}$. This indicated that the decrease in density with the increase in percent replacement of sand by saw dust and coarse aggregate by EPS. The results showed that the concrete become lightweight concrete with the increase in amount of saw dust and EPS. The water absorption of M20 concrete brick sample varied from $1.99 \%$ to $3.59 \%$. This resulted that with the increase in percentage replacement of sand by saw dust and coarse aggregate by EPS, the water absorption increases. The water absorption of M15 concrete brick sample varied from $3 \%$ to $5.05 \%$. This resulted that with the increase in percentage replacement of sand by saw dust and coarse aggregate by EPS, the water absorption increases.

With the use of saw dust for partial replacement of sand and EPS as partial replacement of coarse aggregate in concrete brick, compressive strength of prepared concrete brick sample decreased as compare to M15 and M20 concrete brick. When compared with common brick, average compressive strength obtained in each sample type has sufficient strength.

\section{Recommendation}

It is recommended for further study of the effect of additives on mechanical properties of saw dust and EPS concrete brick samples .Also the study on properties of saw dust and EPS concrete hollow block samples can be done. 


\section{References}

1. Adewuyi, A., \& Adegoke, T. (2008). "Exploratory Study of Periwinkle Shells as Coarse Aggregates in concrete works".Journal of Applied Sciences Research, 4.

2. Agbede, O., \& Monash, J. (2009). "Suitability of Periwinkle Shell as Partial Replacement forGravel in concrete". Leonardo Electronic Journal of Practice and Technologies, 15.

3. Gawale, R., Mishra, S., Sambare, H., Kothari, J., \& Patil, M. (2016). "Light Weight Concrete bY Using EPS Beads". ICETEMR.

4. Kumar, D., Singh, S., Kumar, N., \& Gupta, A. (2014). "Low Cost Construction Material for Concrete as Sawdust". Global Journals, 14.

5. Mandlik, A., Sood, T. S., Karade, S., Naik, S., \& Kulkarni, A. (2013). "Lightweight Concrete Using EPS". International Journal of Science and Research.

6. Olutoge, F. (2010). "Investigations on Sawdust and Palm Kernel Shells as AggregateReplacement". 5

7. T.N.Boob. (2014). "Performance of Saw-Dust in Low Cost Sandcrete Blocks. American Journals of Engineering Research", 3. 